\title{
Migrants are Colonized by Resistant Bacteria during their Prolonged Stays in Refugee Camps
}

P. Hajj Ali (Peri Haij Ali)', F. Sasvary (Ferdinand Sasvary)4 ${ }^{4}$ V. Krcmery (Vladimir Krcmery)1,6, M. Jankechova (Monika Jankechova)1, 5. Putekova (Silvia Putekova)², J. Kabatova (Jana Kabatova)², L. Tkacova (Lubomira Tkacova)․, A. Murgova (Anna Murgova)1, J. Bydzovsky (Jan Bydzovsky)1,6, A. Topolska (Alexandra Topolska)', L. Bucko (Ladislav Bucko)․, M. Palenikova (Milica Palenikova)', A. Liskova (Anna Liskova)', L. Tomic (Liana Tomic)1,4, L. Cervena (Lenka Cervena)', I. Khalil (Ibrahim Khalil) ${ }^{1}$, H. Heiderova (Hana Heiderova) ${ }^{1}$ and G. Herdics (Gyorgy Herdics) ${ }^{1,4}$

Original Article

${ }^{1}$ St. Elizabeth University Refugee Program, PhD. and MHA Program, SK

${ }^{2}$ University of Trnava School of Health, SK

${ }^{3}$ Commenius University School of Medicine Bratislava, SK

${ }^{4}$ Health Post Vamoszabadi, HU

${ }^{5}$ Health Post Nickelsdorf, AT

${ }^{6}$ Field Hospital Dobova, SI

\section{E-mail address:}

georgiuspaulus@gmail.com

\section{Reprint address:}

Gyorgy Herdics, Ph.D., MBA

St. Elisabeth University, Bratislava

P. O. Box 58

93005 Gabcikovo, SK

Suource: Clinical Social Work and Health Intervention Pages: $15-18$
Volume: 8

Cited references: 10
Issue: 1

\section{Reviewers:}

Magesvari Rajoo, MSc.

SARMM, Kuala Lumpur, MY

Dr. Roberto Cauda, Ph.D., MD

Institute of Infectious Diseases

Catholic University of the Sacred Heart, Rome, IT

\section{Key words:}

Migrants, Migrant crisis, Antibiotic resistance. 


\section{Publisher:}

International Society of Applied Preventive Medicine i-gap

CSWHI 2017; 8(1): 15 - 18; DOI 10.22359/cswhi_8_1_03 @ 2017 Clinical Social Work and Health Intervention

\section{Abstract:}

Despite 1.5 million migrants (MM) and refugees using the Balkan Route from Syria/Iraq via Turkey, Greece, Serbia, Croatia, Slovenia or Hungary to Austria and Germany and smoldering exodus of 250,000 MM via Mediterranean Route, who entered Italy, Spain and Malta from the African continent, every year for 10 years at least, no major epidemics were noted. Reasons for this may vary, but there is public concern of transmitting resistant micro-organisms to Europe. The aim of the study was to estimate whether there is such a risk; where are migrants colonized by bacteria; what type of bacteria are they carrying. Migrants are colonized by bacteria during prolonged stay in refugee camps in inappropriate conditions; migrating migrants are not hosts for resistant bacteria. Conditions in camps should be addressed to prevent spreading resistant micro-organisms.

\section{Conflict of interest:}

The authors whose names are listed in the title of the article certify that they have NO affiliations with or involvement in any organization or entity with any financial interest (such as honoraria; educational grants; participation in speakers' bureaus; membership, employment, consultancies, or other equity interest), or non-financial interest (such as personal or professional relationships, affiliations, knowledge or beliefs) in the subject matter or materials discussed in this manuscript.

\section{Introduction}

Fortunately, the refugee crisis in the EU has not yet had major any health consequences. Despite 1.5 million migrants (MM) and refugees using the Balkan Route from Syria/Iraq via Turkey, Greece, Serbia, Croatia, Slovenia or Hungary to Austria and Germany and smoldering (slow flow) of $250,000 \mathrm{MM}$ via the Mediterranean route entered from the African continent via Malta, Italy and Spain every year for last 10 years at least, no major epidemics were noted. Only sporadic cases of Hepatitis A, Scabies and non-specific diarrhea were noted. Even epidemic diseases like influenza, decimating every early Spring in Central Europe, or cholera so typical for mass gathering and migrating weren't noted.

There are several reasons why it may be possible:

- Good health infrastructure in (partially) EU transiting countries (Italy, Malta, Greece, Croatia, Serbia, Hungary, Austria),

- Healthy population migrating (young adolescents, children with families),

- Acceptable vaccination status apart of very small infants from Syria (Tulio Prestilio 2015), 
- Good health and overall education of MM on prevention and early therapy of infectious diseases,

- Screening for some infectious diseases during transit.

However, Points 3 and 4 are present only among those migrating via Balkan and not via Mediterranean Route.

On the negative side of the coin are the substantial ship tragedies off Malta, Lampedusa and Sicily, resulting to 6,000 to 10,000 non-infectious deaths.

\section{Patients and methods}

Samples from oropharynx of 40 migrating migrants between Hegyeshalom (HU) and Nickelsdorf (AT) were obtained between Sept. - Nov. 2016. Stationary migrants/asylum seekers were located in Veria/Alexandria from refugee camps (1,016 samples). Swabs were taken from symptomatic patients and transported to the National Reference Laboratory. Resistance to antimicrobial patterns in both groups were compared and assessed.

\section{Results and discussion}

Comparing the etiology in respiratory isolates of both groups, there was a significant difference in S. aureus and Candida spp. among both groups. S. aureus was significantly more frequent among migrants residing for 3-6 months in a refugee camp (12.2\% vs $2 \% \mathrm{p}<0.01$ ) and Candida spp. (C.albicans 7, and non-Albicans Candida spp. 3) as well. Also, the overall member of pathogens colonizing the respiratory systems of migrants was significantly higher among migrants in camp in comparison to migrating migrants in the Nickelsdorf or Hegyeshalom

Table 1 Stationary migrants in Greek migrant camp Alexandria versus migrating migrants in the Balkan Route: discrepancies in colonization of the RTI with respiratory infections diseases pathogens.

\begin{tabular}{|l|c|c|c|}
\hline & $\begin{array}{c}\text { Stationary } \\
\text { Migrants } \\
\text { SM }\end{array}$ & $\begin{array}{c}\text { Migrating } \\
\text { Migrants } \\
\text { MM }\end{array}$ & P \\
\cline { 4 - 4 } & 48 & 101 & \\
\hline A) Grampositive Bacteria & & & \\
\hline S. aureus & $5^{*}$ & 2 & $\mathrm{P}<0,01$ \\
\hline MSSA & 4 & 2 & \\
\hline MRSA & 1 & 0 & \\
\hline St. pyogenes (ERY-R) & 1 & 1 & \\
\hline St. pneumoniae (PEN-) & 0 & 2 & \\
\hline Total & 6 & 7 & \\
\hline B) Gramnegative & & & \\
\hline HOCA & 1 & & \\
\hline HAIN & 1 & & \\
\hline Enterobacteriaceae & 2 & 6 & \\
\hline Pseudomonacae & 1 & 1 & \\
\hline Total & 5 & 7 & \\
\hline Candida spp. (total) & 10 & 2 & $\mathrm{P}<0,01$ \\
\hline C. albicans & 7 & 2 & \\
\hline NAC & 3 & 0 & \\
\hline
\end{tabular}


Health Posts (22 of 45, 48.5\% vs. 15 of 101 , $15 \%, \mathrm{P}<0.05$ ). Some rare (marine) organism such as Ps. stutzei, Neisseria fermentans and others were isolated from the migrating migrants subgroups, indicating having crossed the sea during traveling. (1-5) Surprising findings were of a significantly higher population of bacterial and fungal pathogens when comparing the respiratory isolates in stationary migrants compared to migrating migrants which indicates that SM are much more frequently colonized with bacteria pathogens and pathogens transferred during long-term stays in the facility. (6-10)

\section{Conclusions}

Migrants in camps and closed communities might be at significantly higher risk of infection with resistant strains of bacteria, than those who are on the move. However, more studies are needed to confirm this hypothesis. Prolonged stays in camps without proper nutrition and living conditions should be matters of concern as well.

\section{References}

1. BAKER MG, FIDLER DP (2006) Global Public Health Surveillance under New International Health Regulations. Emergency Infect Dis.; 12(7):1058-1065.

2. KRCMERY, V ET AL. Respiratory infections after camping in free nature are the current diseases in Migrants to Austria and Germany via Hungary in September 2015: Experience from Röszke and Vámoszabadi. Neuroendocrinology Letters. vol 33, sup$\mathrm{pl}, 1,2013$

3. HAJJ PA ET AL. Are migrants from Middle East carriers of multi-resistant bacteria? Clinical Social Work and Health Intervention Vol. 7 No. 32016 THE GLOBAL FUND (2015) Results Report ISBN 9789292244354

4. PRESTILEO T, DI LORENZO F, CORRAO S (2015) Infectious Diseases among
African irregular migrants in Italy. Just an individual problem? Clin. Soc. Work, 5, 45

5. SRAMKA, M., RUZICKY, E., FURDOVA, A., CHORVATH, M., KAJAN, J., MAZAN, P., FURDA, R., MOLNAR, E. (2016) Possibilities in $3 D$ Printing by radiosurgical operations. In: Health and Social Work. ISSN 13336-9326. Vol. 11, No 3, p. 15-20.

6. GAZIKOVA, E. 2016. Relief Program child's family environment in order to adjust family relationships incurred by the operators. In Social work in uncertain times: Proceedings of specialized articles XII. Hradecké dny sociální práce 23. a 24. záríi. 2016. Hradec Králové: Gaudeamus, 2016. ISBN 978-80-7435-647-6, s. 407-412.

7. KRCMERY V, KALAVSKY E (2007) Antibiotic Resistance in "ATB free" environment. Neuroendocrinology Letters, 28, 83, p. 33-34.

8. MIKLOSKOVA, M, FERO, M, BYTCANEKOVA, J (2016). The reunification of the child with the family - factors on the family side influencing the child's return from the institutional care In: Suvada J., Czarnecki P., Bujdova N. Social Pathology within the Family, Warsaw Management University, Warsaw 2016, ISBN 978-837520-218-2

9. FAVILA E, ECHEVARRIA J, RUBAKI S, VINICZAI V (2015) Health assistance of displaced people along the Balkan route The Lancet, 386, Dec. 19, 2475

10. KHALED I, CAUDA R, TAKAC B, BURIANCOVA K, PUTEKOVA S, MARTINKOVA J, LACHYTOVA, L (2016). Screen or not to screen? 7 questions in prevention of infection from refugees and migrants. Clinical Social Work and Health Intervention, 7(3), 16-18. doi:10.22359/cswhi_7_3_04

11. PRESTILEO T, DI LORENZO F, CORAO $\mathrm{S}$ (2015) Infectious Diseases among African irregular migrants in Italy. Just an individual problem? Clinical Social Work and Health Intervention, 2, 45-57. doi: $10.5604 / 2222386 \mathrm{X}$ 